\title{
Deoxyribonucleotide Triphosphate
}

National Cancer Institute

\section{Source}

National Cancer Institute. Deoxyribonucleotide Triphosphate. NCI Thesaurus. Code C105951.

A nucleotide comprised of either a purine or pyrimidine nitrogenous base bound to a deoxyribose sugar esterified with three phosphate groups. These molecules are essential for DNA synthesis. 